\title{
Multidimensional Poverty and the State of Child Health in India
}

Sanjay K. Mohanty

CR Parekh Visiting Fellow

Asia Research Centre

London School of Economics and Political Science

Houghton Street,

London

WC2A 2AE

United Kingdom 


\section{Multidimensional Poverty and the State of Child Health in India}

Written by: $\quad$ Sanjay K. Mohanty

Sanjay K. Mohanty was C R Parekh Visiting fellow at Asia Research Centre, LSE, 2009-10 and Associate Professor, Department of Fertility Studies, International Institute for Population Sciences, Govandi Station Road, Deonar, Mumbai- 400088, India.

Email: sanjayiips@yahoo.co.in, sanjay@iips.net

All rights reserved. Apart from any fair dealing for the purpose of research or private study, or criticism or review, no part of this publication may be reproduced, stored in a retrieval system or transmitted in any form or by any means without the prior permission by the publisher or author.

Copyright $@$ C Sanjay K Mohanty 2010

For further information, please contact

Asia Research Centre (ARC)

London School of Economics \& Political Science

Houghton Street

London WC2A 2AE

$\underline{\text { www.lse.ac.uk/collections/AsiaResearchCentre }}$ 


\section{ACKNOWLEDGMENTS}

My assignment as the C.R. Parekh Visiting Fellow at the Research Centre (ARC), London School of Economics and Political Science was memorable, productive and pleasant. During my stay (January-April 2010), I have benefited immensely from the academic environment at the ARC and the School. With the kind permission of course teachers, Dr Jouni Kuha, Dr Sally Stares and Dr Elliot Green, I attended three courses: Special Topics in Quantitative Analysis (MI 456); Quantitative Analysis III: Applied Multivariate Analysis (MI-455); and Poverty (DV 407). I have completed my research paper entitled, "Multidimensional Poverty and the State of Child Health in India", within the stipulated time. The findings of my research were presented at a seminar on March 16, 2010 in room no S 78, St Clement's House, LSE. I thank the participants for their useful suggestions. and the anonymous reviewer for providing thoughtful suggestions that helped me to revise the paper.

I had the opportunity to meet and discuss my research topic with Dr Ruth Kattumuri, Dr Athar Hussain, Dr Elliot Green and Prof John Cleland and incorporated their valuable suggestions. My deep gratitude to the ARC for awarding me the C.R. Parekh fellowship and to the Nirman Foundation for the generous financial support that enabled me to carry out the work. I would like to thank Dr Ruth Kattumuri for all her help, from academics to administration and for making my stay comfortable. I thank Mr. Keith Tritton and Mr. Kevin Shields for providing me prompt administrative support at all stages of my work. I also thank the previous Centre Manager, Mr. Scott Shurtleff and the accommodation office at LSE for providing me excellent accommodation at Sidney Webb House.

My gratitude to Prof F.Ram, Prof T.K.Roy, Prof P.C. Saxena and Prof R.K. Sinha for their encouragement. I thank Dr. Bijaya Malik for his constant support, Mr Ranjan Pursty who helped me to draw the maps and Ms Sudha Raghavendran for editing the paper, Ms Lipika and Mr Siddhant for their dedicated help and the Almighty for shaping my career.

Sanjay Kumar Mohanty

01.11 .2010 


\title{
Multidimensional Poverty and the State of Child Health in India
}

\begin{abstract}
Using data from the National Family and Health Survey 3, India, this paper measures and validates the extent of multidimensional poverty and examines the linkages of poverty level with child health in India. Multidimensional poverty is measured in the domain of education, health and living standard and child health is measured with respect to infant mortality rate, the underfive mortality rate, immunization of children and medical assistance at birth. Results indicate that one-fifth of the households in India are abject poor; half of them are poor and the poor have limited access to child care. While infant mortality rate and under-five mortality rate are disproportionately higher among the abject poor compared to the non-poor, there are no significant differences in child survival among the educational, economical and health poor at the national level. Regional patterns in child survival among education, economical and health poor are mixed.
\end{abstract}

Key words: multidimensional poverty, infant mortality, under-five mortality, India, child health 


\section{Introduction}

The goal of this paper is both methodological and empirical. The methodological goal is to measure the state of multidimensional poverty and the empirical goal is to examine the state of child health among the abject poor, poor and non-poor households in India. This paper has been conceptualized with the following rationale; First, though multidimensional poverty has been acknowledged cutting across disciplines (among economists, development thinker, social scientists, public health professionals, policy makers and international organizations) and included in the development agenda, its measurement and application are still limited. Second, poverty eradication program in India identifies poor using the concept of multidimensional poverty but the official estimates of poverty continue to be derived from consumption expenditure data. Third, empirical evidence suggests an inverse association of level and inequality in child survival, that is, as mortality declines, the gap in child mortality between the poor and the better-off widens (Wang 2003). Four, in transitional economies, health care services are more likely to benefit the non-poor than the poor (Gwatkin 2005). Along with these goals and rationale, we hypothesize that there are no significant differences in child survival (infant mortality rate and under-five mortality rate) among the educational poor, wealth poor and health poor.

In deriving multidimensional poverty, both theoretical and methodological issues are of immense importance. Methodological issues include the fixing of a cut off point for the poor and nonpoor, aggregation of multiple dimensions into a single index, weighting of dimensions and the unit of analyses, while theoretical issues relate to the choice of dimensions, choice of indicators and the context (Alkire and Foster 2009; Alkire 2007). The UNDP has devised two composite 
indices, namely the Human Poverty Index 1 (HPI 1 for developing countries) and Human Poverty Index 2 (HPI 2 for developed countries) to measure the state of multidimensional poverty in the domain of health, knowledge and living standard (UNDP 1997). Among researchers, there is general agreement in specifying the poverty line of each dimension, but they differ in deriving the aggregate poverty line. While some have used the union approach (poor in any dimension) (Bourguignon and Chakravarty 2003), others have used the intersection (poor in two or more dimension) approach (Gordon et al 2003) or relative approach (Wagle U 2007) in fixing the poverty line. On the theoretical front, the dimensions of education, health and income are often measured and few studies have included subjective well being such as fear to face hardship (Calvo 2008) in defining multidimensional poverty. Studies also document varying degrees of correlation between dimensions of poverty or deprivation (Klasen S 2000).

Traditionally in the domain of income/consumption, poverty estimates were primarily based on income and/or consumption expenditure survey data. More recently, data from the Demographic and Health Surveys (DHS) were used in estimating poverty. Sahn and Stiefel (2000) estimated the change in poverty of African countries in the 1990s using the asset based welfare index. Along with consumer durables and housing characteristics, they had used the educational level of head of household in defining poverty. Booysen, Maltitz and Rand (2008) extended the work of Sahn and Stiefel to seven African countries and found a decline in the poverty in five of these countries. Srinivasan and Mohanty (2008) using three rounds of Indian DHS data, estimated the change in deprivation level in Indian states. 
In India, the estimates of poverty and the identification of poor for conditional cash transfer are carried out independently. The official estimates of poverty are derived by the Planning Commission based on consumption expenditure data collected by the National Sample Survey Organization (NSSO) in its quinquinneal round (since 1973-74). On the other hand, the poor are identified by a Below Poverty Line (BPL) Survey carried out by the District Rural Development Authority (DRDA) of each state with guidelines from the Ministry of Rural Development, Government of India. Based on the Planning Commission, Government of India estimates of 2004-05 (uniform recall period), $27 \%$ of India's population ( $25.7 \%$ urban and $28.3 \%$ rural) were living below the poverty line (Planning Commission 2007). However, these estimates are often debated and revised owing to different recall periods (365 vs. 30 vs. 7 days) in various rounds, the fixed basket of goods and services, the price index applied and appropriate minimum threshold. Additionally, the consumption expenditure is sensitive to household size and composition and not adjusted in poverty estimates. Recently, the Government of India appointed the Tendulkar Committee to suggest an amendment of poverty estimates. The Committee recommended the same poverty estimates for urban India $(25.7 \%)$ but re-estimated rural poverty for 2004-05 (Planning Commission 2009). On the other hand, three rounds of BPL survey had already been carried out with different methodology for identifying the poor. The first BPL survey was conducted in 1992, the second in 1997 and the third in 2002. There were improvements in the methodology in successive rounds of BPL surveys but all these rounds used the concept of multidimensional poverty. For example, the 2002 round used a set of 13 socioeconomic indicators (size of operational land holding, type of house, availability of food and clothing, security, sanitation, ownership of consumer durables, literacy status, status of household labour, means of livelihood, status of school going children, type of indebtedness, 
reason for migration and preference of assistance) with a score ranging from 0 to 4 for the variables. The total score ranged from 0 to 52 and the states were given the flexibility of deciding the cut off points. There has been discontent on the methodology used in BPL surveys and misuse in the distribution of BPL cards (Sundaram 2003; Ram et al 2009).

Evidence in India suggests reduction in consumption poverty, but the state of child health has not improved substantially. During 1992-2006, the proportion of undernourished children had declined marginally (about two-fifths of children were undernourished in 2005-06). The infant mortality rate had declined from 77 deaths per 1000 live births in 1991-95 to 57 per 1000 live births in 2001-05 (IIPS and Macro International 2007). Though there is a large differential in the state of child health and health care utilization by education and wealth status of the households, little is known on the state of child health by multiple deprivations. This paper attempts to measure the deprivation in multiple dimensions of capability and understand its linkage with child survival in India, using large scale population based survey data.

\section{Data and Methods}

In the last two decades, the Demographic and Health Surveys (DHS) have bridged the data gap on population, health and nutrition parameters of many developing countries, including India. The DHS in India, known as the National and Family and Health Survey (NFHS), was first conducted in 1992-93 and the second and the third rounds were conducted in 1998-99 and 200506 respectively. The NFHS's are large scale population based representative sample surveys that cover more than $99 \%$ of India's population under rigorous conditions of scientific sampling design, training of investigators and high quality data collection and edit procedures. These 
surveys collect reliable information on births, deaths, family planning, nutrition, a range of health related issues including HIV/AIDS and the living conditions of households. There were improvements in coverage and dimensions in successive rounds of the survey. NFHS-3 canvassed three different survey instruments namely, the household schedule, the women's questionnaire and the men's questionnaire from the sampled households. The household schedule collected information on economic proxies such as housing quality, household amenities, size of land holding and consumer durables, whereas the women questionnaire collected detailed information on reproductive histories, health, nutrition and related information of mothers and children. The men's questionnaire collected information on men's involvement in health care, reproductive intention and knowledge and use of contraception from men in the age group 15-54. A detailed description of the survey design of the NFHS and the findings are available in the national report (IIPS and Macro International 2007). In this paper we have utilized the data of NFHS-3 that covered a sample of 109,041 households and 124,385 women in the country (Table 1 (a)). The household file, women's file, birth history file and the member files are used in the analysis.

Table 1 (a): Number of un-weighted households, households with women and children covered in 2005-06, India

\begin{tabular}{|c|c|c|c|}
\hline Households/ Women & Combined & Rural & Urban \\
\hline Number of Households & $1,09,041$ & 58,805 & 50,236 \\
\hline Number of households with at least one women aged 15-59 & 90,014 & 48,927 & 41,087 \\
\hline Number of households with at least one child aged 0-59 months & 40,593 & 23,961 & 16632 \\
\hline Number of households with at least one child aged 7-14 years & 53,230 & 31,121 & 22,019 \\
\hline Number of women interviewed & 124,385 & 67,424 & 56961 \\
\hline
\end{tabular}

We have measured multidimensional poverty in the dimension of education, health and living standard of the household. The dimension of education includes literacy status of all adult members and the current schooling status of school going children in the households. The dimension of health includes child health and the health of women in the age group 15-49. Child 
health is measured by a set of health care variables (the vaccination coverage of children, the medical assistance at delivery), infant mortality rate (IMR) and under-five mortality rate (U5MR). The living standard is measured by a set of economic proxies of the household. In deriving the estimate of multidimensional poverty, the unit of analysis is the household, whereas the child is the unit of analysis for child health variables. The estimates of IMR and U5MR are derived from the birth history file and analyses were carried out separately for rural and urban areas. NFHS data has been used for all the analyses. All the data from NFHS has been weighted to adjust for non-response (IIPS and Macro International 2007). The national weight is used in the national analyses and state weight is used in state level analyses. The basic objective of state weight is to maximize the representativeness of the sample in terms of the size, distribution, and characteristics of the study population. Specifically it takes care of the non-equal probability of selection in different domain i.e., rural and urban areas and slum and no-slum areas in the states of Andhra Pradesh, Delhi, Madhya Pradesh, Maharashtra, Tamil Nadu, Uttar Pradesh and West Bengal. It also takes care of the differential non-response rates of household interviews in urban and rural areas and slums and non-slums. After adjusting for non-response, the weights are normalized so that the total number of weighted cases is equal to total number of unweighted cases. Because of the normalization of the state household weight at the state level, the normalized state household weight cannot be used for national indicators. Hence the national weight is the product of design weight of each state and the state weight. SPSS 14 and STATA 10 software packages are used. Bi-variate analysis is used in understanding the differentials in poverty and health care, while the principal component analysis (PCA) is used in estimating the wealth index. The life table technique is used to estimate the IMR (probability of dying in first 
year of life) and the U5MR (the probability of dying within first five years of life) by poverty level of the household.

\section{Results}

Results are presented in three sections. Section 1 describes the methodology of identification of poor and estimates of multidimensional poverty, section 2 describes health care utilization by poverty level and section 3 describes child survival among the abject poor, poor but not abject poor and non-poor.

\section{1: Identification of the Poor and the Extent of Multidimensional Poverty}

Table 1 (b) show the specific indicators used in quantifying dimensional poverty in education, health and living standard separately for rural and urban areas. It also provides the method of fixing the cut off point of poor in each of these dimensions. 
Table 1 (b): Dimensional indicators of poverty and the method of deriving poor in India

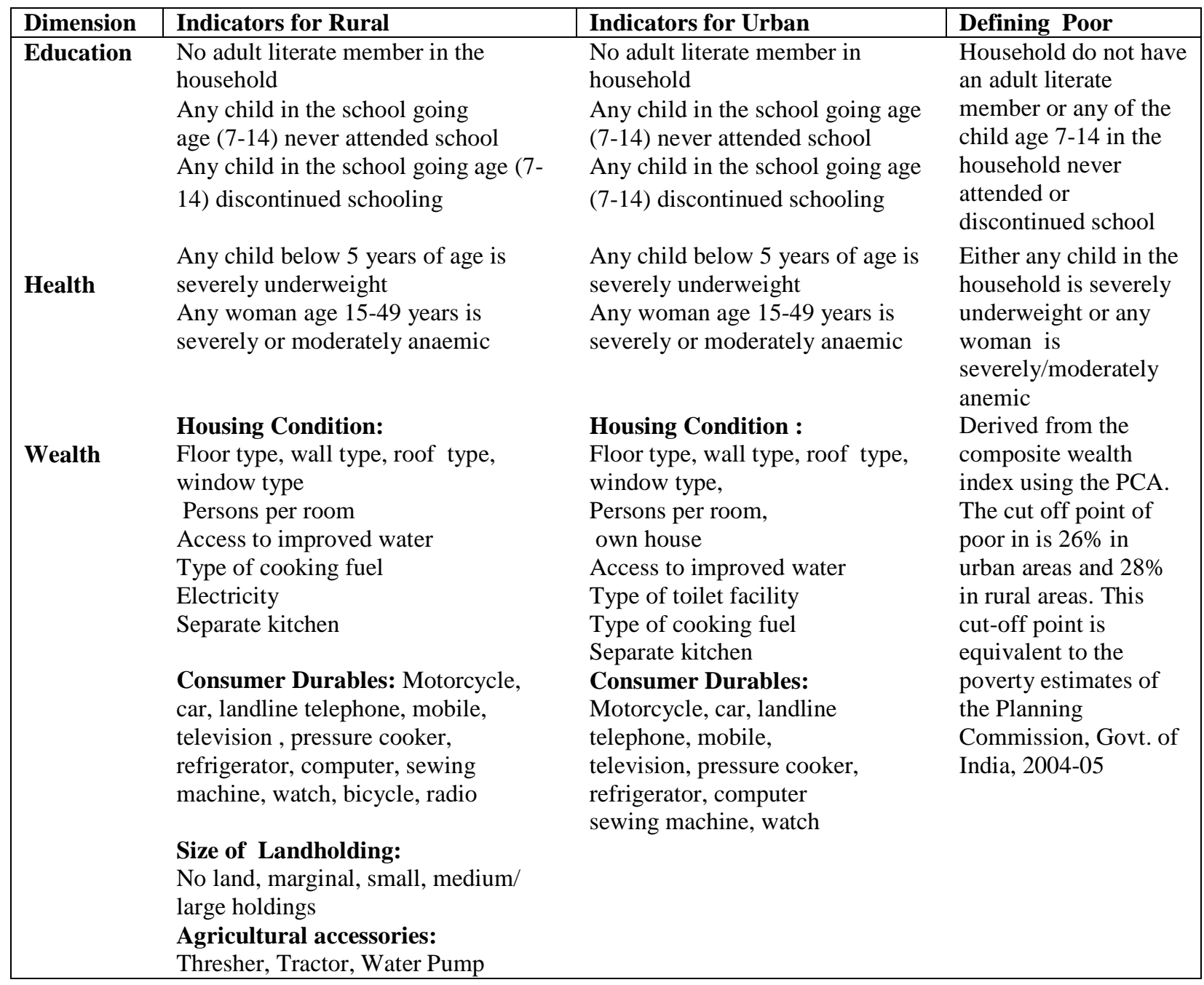

In the dimensional index of education, three indicators, namely, any adult literate member $(15+)$ in the household and children in the school going age who had never attended school or had discontinued schooling are used. The literacy status of any adult member in a household is the basic and frequently used indicator that measures literacy. It is computed by the presence or absence of any adult literate member in the household. We prefer to use this indicator to that of the head of household as the average age of the household head is 46 years in the country. In such cases, the recent benefits of education (say in last 10-15 years) to the members of household 
will not be captured, while the educational level of any adult member will capture such changes. Second, the official age of child schooling in India is 6-14 years but we prefer to use the age group 7-14 years because the survey was conducted during November 2005-August 2006 and the child's age was estimated as of the survey date. For example, a child who might have completed six years in January 2006 may be admitted to school in June 2006. If the survey had taken place in January 2006, the child would not have been counted as 'attending school. Hence, we prefer to consider the age group 7-14 years for child schooling in our analyses. We define a household as poor in the education domain, if the household does not have a single adult literate member or if any of the children in the school going age are out of school (include both never enrolled and discontinued schooling). It was found that $20 \%$ of the households did not have an adult literate member, $9 \%$ of the households had at least one child who had never gone to school and $4.8 \%$ households had at least one child who had discontinued schooling.

Table 2 (a): Mean and standard deviation of dimensional indicators of education and health in India by place of residence, 2005-06

\begin{tabular}{|c|c|c|c|c|c|c|}
\hline \multirow[t]{2}{*}{ Dimensional Indicators } & \multicolumn{2}{|c|}{ Combined } & \multicolumn{2}{|c|}{ Rural } & \multicolumn{2}{|c|}{ Urban } \\
\hline & Mean & $\begin{array}{l}\text { Standard } \\
\text { Error }\end{array}$ & Mean & $\begin{array}{l}\text { Standard } \\
\text { Error }\end{array}$ & Mean & $\begin{array}{l}\text { Standard } \\
\text { Error }\end{array}$ \\
\hline Education & & & & & & \\
\hline Households without a single adult literate member & 0.198 & 0.0012 & 0.253 & 0.0017 & 0.085 & 0.0012 \\
\hline $\begin{array}{l}\text { Households with at least one child ( } 7-14 \text { years) who } \\
\text { has never gone to school }\end{array}$ & 0.085 & 0.0008 & 0.104 & 0.0013 & 0.044 & 0.0009 \\
\hline $\begin{array}{l}\text { Households with at least one child aged ( } 7-14) \text { years } \\
\text { who has discontinued schooling } \\
\text { Health }\end{array}$ & 0.048 & 0.0006 & 0.054 & 0.0009 & 0.035 & 0.0008 \\
\hline $\begin{array}{l}\text { Household with at least one women aged 15-49 } \\
\text { years who is severely/ moderately anaemic }\end{array}$ & 0.164 & 0.0011 & 0.176 & 0.0016 & 0.14 & 0.0015 \\
\hline $\begin{array}{l}\text { Households with at least one child aged 0-59 months } \\
\text { who is severely underweight }\end{array}$ & 0.058 & 0.0007 & 0.071 & 0.0010 & 0.03 & 0.0007 \\
\hline
\end{tabular}

In the dimension of health, the weight of children below 5 years and the anaemia level of women (both married and unmarried) in the age group 15-49 is used in the analyses. These indicators are widely recognized health measures for children and mothers. However, as $43 \%$ children under age five are underweight and 55\% women are anaemic (either moderate or mild or severe) in the 
country, we prefer to use the severity in these parameters in defining the health domain. We consider a household poor in the health domain if the household has at least a child who is severely underweight or a woman who is severely or moderately anemic. It may be mentioned that information on blood sample was not collected in the state of Nagaland and so the variable for the state is not used.

In the wealth domain, economic proxies (housing conditions, household amenities, consumer durables, size of land holding) of the household are usually used in explaining the economic differentials in population and health parameters as DHS does not collect data on income or consumption expenditure. These economic proxies are combined to form a composite index, often referred to as the wealth index and the PCA is the most frequently used method in deriving the wealth index. The utility of wealth index in explaining economic differentials in population and health parameters have been established (Rutstein and Johnson 2004; Filmer and Pritchett 2001). However, our wealth index differs from the DHS wealth index in many aspects. First, we have constructed the wealth indices for rural and urban areas separately using the PCA, as estimates of health care utilization differ significantly when separate wealth indices are used for rural and urban areas rather than a single index (Mohanty 2009). Second, we have carefully selected variables based on theoretical and statistical significance in the construction of the wealth index for rural and urban areas. For example, the DHS wealth index does not include land in the construction of the wealth index, but uses agricultural accessories such as tractors and threshers. We have used agricultural related variables for rural but not for urban areas. Similarly, in rural areas a large proportion of households own a house, therefore we have not included this variable in the construction of the wealth index for rural India. Third, we have equated the cutoff point of the poor to the Planning Commission, Government of India estimates of poverty in 
2004-05, based on uniform recall period. Accordingly, $26 \%$ of urban households and $28 \%$ of rural households were considered poor in the economic domain.

Table 2 (b): Mean, standard deviation and factor score of variables used in the construction of wealth index by place of residence, India, 2005-06

\begin{tabular}{|c|c|c|c|c|c|c|}
\hline Variables & Rural & SD & $\begin{array}{l}\text { Factor } \\
\text { score }\end{array}$ & Urban & SD & Factor score \\
\hline Housing quality & & & & & & \\
\hline Floor type & 0.305 & 0.460 & 0.253 & 0.807 & 0.395 & 0.212 \\
\hline Wall type & 0.533 & 0.499 & 0.237 & 0.889 & 0.314 & 0.204 \\
\hline Roof type & 0.714 & 0.452 & 0.165 & 0.924 & 0.265 & 0.166 \\
\hline No window & 0.412 & 0.492 & -0.239 & 0.151 & 0.358 & -0.216 \\
\hline Window without cover & 0.290 & 0.454 & 0.022 & 0.216 & 0.411 & -0.109 \\
\hline Window with cover & 0.299 & 0.458 & 0.235 & 0.633 & 0.482 & 0.253 \\
\hline \multicolumn{7}{|l|}{ Person per room } \\
\hline Two person & 0.325 & 0.468 & 0.056 & 0.376 & 0.484 & 0.093 \\
\hline $2-4$ & 0.426 & 0.494 & 0.026 & 0.431 & 0.495 & -0.002 \\
\hline $4+$ & 0.249 & 0.433 & -0.090 & 0.193 & 0.395 & -0.111 \\
\hline Own house & 0.933 & 0.250 & $* * *$ & 0.782 & 0.413 & 0.042 \\
\hline Improved drinking water & 0.848 & 0.359 & 0.048 & 0.960 & 0.196 & 0.038 \\
\hline Cooking fuel & 0.088 & 0.283 & 0.233 & 0.601 & 0.490 & 0.285 \\
\hline Electricity & 0.558 & 0.497 & 0.229 & 0.931 & 0.254 & $* * *$ \\
\hline Separate kitchen & 0.440 & 0.496 & 0.173 & 0.634 & 0.482 & 0.241 \\
\hline \multicolumn{7}{|l|}{ Toilet facility } \\
\hline No toilet & 0.740 & 0.438 & $* * *$ & 0.169 & 0.375 & -0.247 \\
\hline Pit toilet & 0.060 & 0.237 & $* * *$ & 0.044 & 0.206 & -0.058 \\
\hline Flush toilet & 0.200 & 0.400 & $* * *$ & 0.787 & 0.409 & 0.255 \\
\hline \multicolumn{7}{|l|}{ Consumer durables } \\
\hline Pressure cooker & 0.221 & 0.415 & 0.283 & 0.699 & 0.459 & 0.266 \\
\hline Television & 0.301 & 0.459 & 0.281 & 0.732 & 0.443 & 0.237 \\
\hline Sewing machine & 0.126 & 0.332 & 0.209 & 0.309 & 0.462 & 0.178 \\
\hline Mobile & 0.074 & 0.261 & 0.227 & 0.363 & 0.481 & 0.243 \\
\hline Telephone & 0.080 & 0.271 & 0.244 & 0.266 & 0.442 & 0.239 \\
\hline Computer & 0.006 & 0.076 & 0.093 & 0.080 & 0.272 & 0.157 \\
\hline Refrigerator & 0.066 & 0.248 & 0.230 & 0.334 & 0.472 & 0.271 \\
\hline Watch & 0.714 & 0.452 & 0.192 & 0.911 & 0.285 & 0.152 \\
\hline Motorcycle & 0.108 & 0.310 & 0.245 & 0.305 & 0.460 & 0.232 \\
\hline Car & 0.010 & 0.099 & 0.122 & 0.061 & 0.239 & 0.145 \\
\hline Radio & 0.270 & 0.444 & 0.161 & 0.389 & 0.487 & $* * *$ \\
\hline Bicycle & 0.517 & 0.500 & 0.083 & 0.501 & 0.500 & $* * *$ \\
\hline \multicolumn{7}{|l|}{ Land and agricultural accessories } \\
\hline No land & 0.415 & 0.493 & -0.057 & 0.810 & 0.393 & $* * *$ \\
\hline Marginal holding (up to 2.5 acer) & 0.392 & 0.488 & -0.036 & 0.111 & 0.314 & $* * *$ \\
\hline Small holding $(2.51-5)$ & 0.082 & 0.275 & 0.111 & 0.038 & 0.192 & $* * *$ \\
\hline Medium/large (5+) & 0.110 & 0.313 & 0.048 & 0.041 & 0.199 & $* * *$ \\
\hline Irrigated land & 0.381 & 0.486 & 0.080 & 0.125 & 0.331 & $* * *$ \\
\hline Water pump & 0.099 & 0.298 & 0.150 & 0.110 & 0.313 & $* * *$ \\
\hline Threshers & 0.022 & 0.147 & 0.082 & 0.004 & 0.065 & $* * *$ \\
\hline Tractors & 0.023 & 0.151 & 0.121 & 0.005 & 0.069 & $* * *$ \\
\hline
\end{tabular}

\footnotetext{
$* * *$ Not used in the analyses
} 
The mean, standard deviation and the factor score (weight) of the variables used in deriving wealth indices are shown in Table 2(b). The weight of the variables generated in the construction of wealth indices are in the expected direction, both in urban and rural areas. The variables that reflect a higher living standard have a positive weight, while those with a lower standard of living have a negative weight. For example, the weight of a flush toilet in urban areas is 0.255 , pit toilet is -0.058 and that of no toilet is -0.247 . The distribution of the wealth index showed that it is positively skewed in urban areas and negatively skewed in rural areas. The alpha value is 0.86 in urban and 0.81 in rural areas indicating that the estimates are reliable. Based on the ascending order of the composite index, a percentile distribution is obtained for the household both in rural and urban areas.

Based on poverty in each dimension, we have classified a household as abject poor, poor but not abject poor and non-poor (Table 3). A household is classified as "abject poor" if it is poor in at least two of the three dimensions and "poor but not abject poor" if it is poor in only one dimension. Similarly, a household is classified as "non-poor" if it is not poor in any one of the dimensions and poor, if it is poor in at least one dimension. Results indicate that $27 \%$ of the households in India are poor in education and wealth dimensions each, while $21 \%$ are poor in the health dimension. The distribution of households in overall multidimensional poverty score suggests that $31 \%$ of the households in India are poor in one dimension, $17 \%$ are poor in two dimensions, $4 \%$ are poor in all three dimensions and $48 \%$ are non-poor. Based on the classification, $20 \%$ of the households in the country are said to be abject poor and $52 \%$ poor (inclusive of abject poor) with large rural-urban differentials. 
Table 3: Percentage of poor in dimension of education, health and wealth and the overall poverty in India, 2005-06

\begin{tabular}{|lccc|}
\hline Poverty levels of Households & Combined & Rural & Urban \\
\hline Percentage of households poor in education & 27.3 & 33.7 & 14.1 \\
Percentage of households poor in health & 20.6 & 22.7 & 16.3 \\
Percentage of households poor in wealth & 27.0 & 28.0 & 26.0 \\
Overall Poverty status & & & \\
Percentage of non-poor households & 48.3 & 43.2 & 58.9 \\
Percentage of households poor in one dimension & 31.4 & 33.4 & 27.7 \\
Percentage of households poor in two dimensions & 16.5 & 19.1 & 11.3 \\
Percentage of households poor in all three dimensions & 3.6 & 4.3 & 2.1 \\
Total Percent & 100 & 100 & 100 \\
Classification of poverty & & & \\
Percentage of Non-poor households & 48.3 & 43.2 & 58.9 \\
Percentage of households Abject poor (Poor in at least two or more dimensions) & 20.1 & 23.4 & 13.3 \\
Percentage of households Poor (Including abject poor) & 51.7 & 56.8 & 41.1 \\
\hline
\end{tabular}

The classification of households on economic, education and health dimensions suggests that those who are economically poor are more likely to be educationally poor cutting across ruralurban boundaries. Among those economically poor, about half of them are educationally poor compared to one-sixth among the economically non-poor. However, the differentials in economically poor and health poor are not large.

We further validated the multidimensional poverty estimates with three critical variables; namely household with a BPL card, an account in a bank or post office and coverage under the health insurance scheme. The possession of a BPL card entitled a household to take benefits from the various poverty eradication schemes of the national and state governments such as subsidized ration, guaranteed employment, free housing and maternal benefits. A higher proportion of abject poor households possess a BPL card compared to the poor or non-poor validate the measure of multidimensional poverty. However, it also indicates that the majority of poor households are not covered under the poverty eradication program. Similarly, 14\% of abject poor households had a bank or a post office account compared to $33 \%$ among the poor but not abject 
poor and 55\% among non-poor indicating the limited access of abject poor and poor to financial institutions. The coverage of health insurance in the population is low and almost non-existent where the abject poor are concerned. These classifications also validate the measure of multidimensional poverty and suggest that the poor are disadvantaged in the service coverage.

Table 4: Percentage of households covered under BPL scheme, access to financial institution, covered under health insurance and living in slums by poverty levels in India, 2005-06

\begin{tabular}{|c|c|c|c|c|}
\hline Combined & Abject Poor & $\begin{array}{l}\text { Poor but not } \\
\text { abject poor }\end{array}$ & Non-poor & All \\
\hline Households have a BPL card & 37.3 & 31.3 & 20.6 & 27.3 \\
\hline Households have an account in a bank or post office & 14.3 & 33.1 & 55.1 & 40.2 \\
\hline $\begin{array}{l}\text { Any adult member in the household covered under a } \\
\text { health insurance scheme }\end{array}$ & 0.6 & 2.9 & 8.2 & 5.0 \\
\hline \multicolumn{5}{|l|}{ Rural } \\
\hline Households have a BPL card & 30.1 & 35.6 & 27.5 & 32.9 \\
\hline Households have an account in a bank or post office & 12.5 & 28.9 & 45.6 & 32.3 \\
\hline $\begin{array}{l}\text { Any adult member in the household covered under a } \\
\text { health insurance scheme }\end{array}$ & 0.2 & 1.6 & 4.0 & 2.3 \\
\hline \multicolumn{5}{|l|}{ Urban } \\
\hline Households have a BPL card & 39.1 & 35.6 & 27.5 & 32.9 \\
\hline Households have an account in a bank or post office & 20.9 & 43.5 & 70.8 & 56.5 \\
\hline $\begin{array}{l}\text { Any adult member in the household covered under a } \\
\text { health insurance scheme }\end{array}$ & 2.1 & 6.3 & 14.8 & 10.7 \\
\hline Lives in a slum & 59.6 & 50.4 & 31.7 & 37.3 \\
\hline
\end{tabular}

Prior research suggests that the extent of multidimensional poverty is higher among female headed households, household heads with low educational level and among large households (Deutsch and Silber 2005; Wagle 2008). We have examined the differentials in multidimensional poverty by selected characteristics of the head of the household such as age, sex, educational level, marital status and household size (Table 5) and found a similar pattern. 
Table 5: Percentage of abject poor and poor not abject poor by characteristics of head of household in India, 2005-06

\begin{tabular}{|c|c|c|c|c|c|c|}
\hline \multirow[t]{2}{*}{ Household head characteristics } & \multicolumn{2}{|c|}{ Combined } & \multicolumn{2}{|c|}{ Rural } & \multicolumn{2}{|c|}{ Urban } \\
\hline & $\begin{array}{l}\text { Abject } \\
\text { poor }\end{array}$ & $\begin{array}{l}\text { Poor but } \\
\text { not abject } \\
\text { poor }\end{array}$ & $\begin{array}{l}\text { Abject } \\
\text { poor }\end{array}$ & $\begin{array}{l}\text { Poor but not } \\
\text { abject poor }\end{array}$ & $\begin{array}{l}\text { Abject } \\
\text { poor }\end{array}$ & $\begin{array}{l}\text { Poor but not } \\
\text { abject poor }\end{array}$ \\
\hline \multicolumn{7}{|l|}{ Age } \\
\hline Up to 30 & 25.9 & 34.6 & 29.4 & 35.1 & 17.7 & 33.4 \\
\hline $31-49$ & 20.6 & 31.4 & 24.0 & 33.1 & 14.0 & 28.2 \\
\hline $50+$ & 17.2 & 30.5 & 20.2 & 33.1 & 10.9 & 25.1 \\
\hline \multicolumn{7}{|l|}{ Sex } \\
\hline Male & 18.6 & 31.4 & 21.8 & 33.2 & 12.3 & 12.3 \\
\hline Female & 28.8 & 32.3 & 32.5 & 34.4 & 20.2 & 20.2 \\
\hline \multicolumn{7}{|l|}{ Educational level } \\
\hline None & 41.0 & 36.5 & 41.1 & 36.8 & 41.1 & 35.2 \\
\hline Up to primary & 13.1 & 35.8 & 14.5 & 35.1 & 12.6 & 37.9 \\
\hline Incomplete secondary & 6.2 & 28.1 & 6.1 & 29.4 & 6.1 & 28.3 \\
\hline Secondary and higher & 1.1 & 14.7 & 1.1 & 21.5 & 1.1 & 15.1 \\
\hline \multicolumn{7}{|l|}{ Marital Status } \\
\hline Never Married & 12.6 & 28.1 & 19.4 & 31.5 & 5.3 & 24.5 \\
\hline Currently Married & 19.3 & 31.4 & 22.5 & 33.2 & 12.7 & 27.7 \\
\hline Widowed/divorced/separated & 26.5 & 33.2 & 29.5 & 35.4 & 20.1 & 28.7 \\
\hline \multicolumn{7}{|l|}{ Household Size } \\
\hline Up to 5 & 18.2 & 29.9 & 22.2 & 32.5 & 11.1 & 25.4 \\
\hline $6-7$ & 20.3 & 31.8 & 23.2 & 33.0 & 13.9 & 29.4 \\
\hline $7+$ & 24.2 & 34.8 & 25.8 & 35.7 & 19.4 & 32.2 \\
\hline
\end{tabular}

Z-test shows significant differences among abject poor and poor but not abject poor, abject poor and non-poor and poor but not abject poor and non-poor

In general, it has been observed that the extent of abject poverty and poverty decreases with age, educational level of households; it is higher among households with many members and among female headed households. For example, the extent of abject poverty was $18 \%$ among households with five or less members compared to $24 \%$ among households with seven members or more. It was $19 \%$ among male headed households compared to $29 \%$ among female headed households.

Given the demographic and developmental diversity in the country, we estimated the extent of multidimensional poverty in the states of India (Table 6) and compared it with consumption poverty estimates based on uniform recall period by the Planning Commission, Government of India for the period 2004-05. 
Table 6: Percentage of abject poor and poor but not abject poor households and the percentage of population living below the poverty line (Planning Commission estimates) in the states of India, 2005-06

\begin{tabular}{|c|c|c|c|c|c|c|c|c|c|c|}
\hline \multirow{2}{*}{\multicolumn{2}{|c|}{ States }} & \multicolumn{2}{|c|}{ Combined } & \multicolumn{2}{|c|}{ Rural } & \multicolumn{2}{|c|}{ Urban } & \multicolumn{3}{|c|}{$\begin{array}{c}\text { Estimates of consumption } \\
\text { poverty, 2004-05 } \\
\text { (Planning Commission) }\end{array}$} \\
\hline & & $\begin{array}{l}\text { Abject } \\
\text { poor }\end{array}$ & $\begin{array}{l}\text { Poor } \\
\text { but not } \\
\text { abject } \\
\text { poor }\end{array}$ & $\begin{array}{l}\text { Abject } \\
\text { poor }\end{array}$ & $\begin{array}{l}\text { Poor but } \\
\text { not } \\
\text { abject } \\
\text { poor }\end{array}$ & $\begin{array}{l}\text { Abject } \\
\text { poor }\end{array}$ & $\begin{array}{l}\text { Poor } \\
\text { but not } \\
\text { abject } \\
\text { poor }\end{array}$ & $\begin{array}{l}\text { Combin } \\
\text { ed }\end{array}$ & Rural & Urban \\
\hline 1 & Kerala & 1.2 & 14 & 0.9 & 13.5 & 1.6 & 15.1 & 15.0 & 13.2 & 20.2 \\
\hline 2 & $\begin{array}{l}\text { Himachal } \\
\text { Pradesh }\end{array}$ & 1.7 & 21.9 & 1.6 & 22.8 & 2.5 & 16 & 10.0 & 10.7 & 3.4 \\
\hline 3 & Goa & 4.2 & 18.7 & 4.1 & 16.4 & 5.3 & 20.2 & 13.8 & 5.4 & 21.3 \\
\hline 4 & New Delhi & 5.6 & 19.6 & 1 & 25 & 5.9 & 19.2 & 14.7 & 6.9 & 15.2 \\
\hline 5 & Punjab & 5.7 & 28 & 4.7 & 30.7 & 7.2 & 23.9 & 8.4 & 9.1 & 7.1 \\
\hline 6 & Sikkim & 5.8 & 30.4 & 5.5 & 32.7 & 7.1 & 21.4 & 20.1 & 22.3 & 3.3 \\
\hline 7 & Mizoram & 6.5 & 20.4 & 7 & 23.3 & 4 & 18 & 12.6 & 22.3 & 3.3 \\
\hline 8 & $\begin{array}{l}\text { Jammu and } \\
\text { Kashmir }\end{array}$ & 7.3 & 30.9 & 8 & 34.2 & 5.3 & 23.5 & 5.4 & 4.6 & 7.9 \\
\hline 9 & Manipur & 8.2 & 26.9 & 7.8 & 23.4 & 9 & 34.3 & 17.3 & 22.3 & 3.3 \\
\hline 10 & Uttaranchal & 8.5 & 26.5 & 8.4 & 28.5 & 8.8 & 21.3 & 39.6 & 40.8 & 36.5 \\
\hline 11 & Haryana & 10.1 & 31.3 & 10.1 & 34 & 10.1 & 25.6 & 14.0 & 13.6 & 15.1 \\
\hline 12 & Maharashtra & 11.2 & 28.7 & 15 & 32.5 & 7.2 & 24.6 & 30.7 & 29.6 & 32.2 \\
\hline 13 & Nagaland & 11.5 & 28.5 & 12.4 & 28.9 & 11.1 & 26.7 & 19.0 & 22.3 & 3.3 \\
\hline 14 & Karnataka & 11.8 & 32 & 12.4 & 35.3 & 10.8 & 27.1 & 25.0 & 20.8 & 32.6 \\
\hline 15 & Gujarat & 12.5 & 33.7 & 14.1 & 36.6 & 10.4 & 29.8 & 16.8 & 19.1 & 13.0 \\
\hline 16 & Tamil Nadu & 13.4 & 32 & 11.8 & 33.2 & 15.2 & 30.6 & 22.5 & 22.8 & 22.2 \\
\hline 17 & Tripura & 13.6 & 29 & 12.5 & 27.2 & 20 & 37.1 & 18.9 & 22.3 & 3.3 \\
\hline 18 & $\begin{array}{l}\text { Andhra } \\
\text { Pradesh }\end{array}$ & 19.5 & 35.9 & 19.1 & 37.2 & 20.6 & 32.9 & 15.8 & 11.2 & 28.0 \\
\hline & India & 20.1 & 31.6 & 23.4 & 33.4 & 13.3 & 27.7 & 27.5 & 28.3 & 25.7 \\
\hline 19 & $\begin{array}{l}\text { West } \\
\text { Bengal }\end{array}$ & 20.4 & 30.4 & 24.4 & 32.2 & 12.1 & 26.6 & 24.7 & 28.6 & 14.8 \\
\hline 20 & Meghalaya & 21.7 & 34.9 & 25.7 & 37.6 & 10 & 27.1 & 18.5 & 22.3 & 3.3 \\
\hline 21 & Assam & 23.1 & 36 & 25.7 & 35.2 & 12.8 & 39.4 & 19.7 & 22.3 & 3.3 \\
\hline 22 & Chhattisgarh & 24.9 & 35 & 27.2 & 35.2 & 16.5 & 34.4 & 40.9 & 40.8 & 41.2 \\
\hline 23 & $\begin{array}{l}\text { Uttar } \\
\text { Pradesh }\end{array}$ & 24.9 & 33.6 & 27 & 35.6 & 18.5 & 27.8 & 32.8 & 33.4 & 30.6 \\
\hline 24 & Rajasthan & 25.4 & 34.2 & 30.7 & 36.5 & 12.5 & 28.5 & 22.1 & 18.7 & 32.9 \\
\hline 25 & $\begin{array}{l}\text { Arunachal } \\
\text { Pradesh }\end{array}$ & 26.1 & 35.7 & 27.7 & 34.9 & 21.9 & 37.5 & 17.6 & 22.3 & 3.3 \\
\hline 26 & Orissa & 28.3 & 32.1 & 30 & 32 & 19.9 & 33 & 46.4 & 46.8 & 44.3 \\
\hline 27 & $\begin{array}{l}\text { Madhya } \\
\text { Pradesh }\end{array}$ & 30.3 & 32.7 & 34.9 & 33.7 & 18.6 & 30.2 & 38.3 & 36.9 & 42.1 \\
\hline 28 & Jharkhand & 37.8 & 31.8 & 45 & 32.3 & 16.6 & 30.2 & 40.3 & 46.3 & 20.2 \\
\hline 29 & Bihar & 39.4 & 31.4 & 41.5 & 32 & 28.3 & 28.2 & 41.4 & 42.1 & 34.6 \\
\hline
\end{tabular}


Based on the estimates of abject poverty, we have classified the states of India as follows;

States with abject poverty of more than 20\%: Bihar, Jharkhand, Madhya Pradesh, Orissa, Arunachal Pradesh, Rajasthan, Uttar Pradesh, Chhattisgarh, Assam, Meghalaya and West Bengal.

States with abject poverty of 10\%-20\%: Andhra Pradesh, Tripura, Tamil Nadu, Gujarat, Karnataka, Nagaland, Maharashtra and Haryana.

States with abject poverty of less than 10\%: Uttaranchal, Manipur, Jammu and Kashmir, Mizoram, Sikkim, Punjab, New Delhi, Goa, Himachal Pradesh and Kerala.

The extent of abject poverty and the overall poverty is maximum in the state of Bihar followed by Jharkhand and minimum in the states of Kerala followed by Himachal Pradesh and Goa. It is observed that the overall poverty is high among states where the extent of abject poverty is high. Further, the pattern of poverty generally follows the state of human development in these states. A comparison of consumption poverty estimates by the Planning Commission, Government of India and the multidimensional poor indicates the large differences in the ranking of poverty. The correlation coefficient of multidimensional poor and consumption poverty in the states of India is weak; 0.27 in urban and 0.65 in rural areas.

We have attempted to understand the correlation of dimensional poor and the correlation of consumption poor and wealth poor in the states of India at the macro level. Among the states of India, the rank order correlation of wealth poor and education poor $(0.78)$ is higher than the correlation of wealth poor and health poor (0.58). However, the correlation of consumption poor and wealth poor are large and significant (0.70). 


\subsection{Poverty and Health Care Utilization}

Many studies documented the rising inequality in health care utilization by economic status of households using direct economic measures (monthly per capita consumption expenditure) or asset based index in India (Mohanty and Pathak 2009). Evidence also suggests that the progress in basic health services like medical assistance at birth and childhood immunization is slow and uneven within the country (Ram et al 2009). In this section, we have examined the differentials in health care utilization with respect to four indicators namely, the usual source of health care of household, medical assistance at delivery, health card (vaccination) of the child and immunization coverage of children. The unit of analyses for utilization of usual health care services is the household, while the child is the unit of analysis for other variables.

The NFHS survey enquires the usual source of health care of the household. Based on the distribution, the usual source of health care has been categorized into the use of health services from the government health centre, the private health centre, the NGO/ Trust and others. A higher proportion of non-poor households mainly depend on the private health services compared to abject poor households. On the other hand, the differentials in use of health services from public health centers are small among abject poor and non-poor. However, a substantially higher proportion of abject poor usually depends on others, largely the traditional health practitioner, chemist and shop. 
Table 7: Differentials in health care utilization (percentage) by poverty level in India, 2005-06

\begin{tabular}{|c|c|c|c|c|c|c|c|c|c|c|c|c|}
\hline \multirow[t]{2}{*}{ India } & \multicolumn{4}{|c|}{ Combined } & \multicolumn{4}{|l|}{ Rural } & \multicolumn{4}{|l|}{ Urban } \\
\hline & $\begin{array}{l}\text { Abject } \\
\text { Poor }\end{array}$ & $\begin{array}{l}\text { Poor } \\
\text { but not } \\
\text { abject } \\
\text { poor }\end{array}$ & $\begin{array}{l}\text { Non- } \\
\text { poor }\end{array}$ & All & $\begin{array}{l}\text { Abject } \\
\text { Poor }\end{array}$ & $\begin{array}{l}\text { Poor } \\
\text { but not } \\
\text { abject } \\
\text { poor }\end{array}$ & $\begin{array}{l}\text { Non- } \\
\text { poor }\end{array}$ & All & $\begin{array}{l}\text { Abject } \\
\text { Poor }\end{array}$ & $\begin{array}{l}\text { Poor } \\
\text { but not } \\
\text { abject } \\
\text { poor }\end{array}$ & $\begin{array}{l}\text { Non- } \\
\text { poor }\end{array}$ & All \\
\hline $\begin{array}{l}\text { Usual source of } \\
\text { health care of } \\
\text { household } \\
\text { Government Health }\end{array}$ & & & & & & & & & & & & \\
\hline Centre & 36.9 & 36.4 & 32.1 & 34.5 & 36.6 & 37.0 & 36.7 & 36.8 & 38.0 & 34.8 & 25.3 & 29.6 \\
\hline Private Health & 49.1 & 53.8 & 60.8 & 56.3 & 47.0 & 51.0 & 53.7 & 51.2 & 56.8 & 60.8 & 71.7 & 66.7 \\
\hline Centre & 0.3 & 0.4 & 0.4 & 0.4 & 0.3 & 0.3 & 0.4 & 0.3 & 0.4 & 0.4 & 0.5 & 0.5 \\
\hline $\begin{array}{l}\text { NGO/Trust } \\
\text { Others }\end{array}$ & 13.7 & 9.5 & 6.6 & 8.9 & 16.1 & 11.7 & 9.2 & 11.7 & 4.8 & 4.0 & 2.6 & 3.2 \\
\hline Place of delivery & & & & & & & & & & & & \\
\hline Home & 80.8 & 58.7 & 37.1 & 57.2 & 86.0 & 67.9 & 49.0 & 67.4 & 58.5 & 30.5 & 14.1 & 28.5 \\
\hline $\begin{array}{l}\text { Government Health } \\
\text { Centre }\end{array}$ & 11.6 & 20.6 & 25.7 & 11.6 & 8.2 & 16.2 & 23.8 & 16.2 & 26.4 & 34.1 & 29.3 & 0.3 \\
\hline Private Health & 7.3 & 20.0 & 36.3 & 7.3 & 5.6 & 15.3 & 26.5 & 15.9 & 14.6 & 34.2 & 55.3 & 40.2 \\
\hline $\begin{array}{l}\text { Centre } \\
\text { Others }\end{array}$ & 0.3 & 0.8 & 0.9 & 0.3 & 0.2 & 0.6 & 0.7 & 0.5 & 0.5 & 1.1 & 1.3 & 1.1 \\
\hline $\begin{array}{l}\text { Medical assistance } \\
\text { at delivery }\end{array}$ & 23.8 & 45.6 & 66.0 & 46.6 & 19.1 & 37.4 & 55.5 & 37.5 & 44.8 & 71.9 & 87.7 & 73.4 \\
\hline $\begin{array}{l}\text { Child (under } 5 \\
\text { years) does not have } \\
\text { a health card }\end{array}$ & 47.6 & 29.3 & 16.0 & 29.7 & 50.2 & 32.6 & 20.0 & 34.0 & 36.3 & 18.8 & 7.9 & 17.3 \\
\hline
\end{tabular}

Z-test shows significant differences among abject poor and poor but not abject poor, abject poor and non-poor and poor but not abject poor and non-poor

The medical assistance at birth is a critical maternal and child care indicator and linked to child survival. During the last decade, several programs including the ongoing Janani Surakhya Yojana (JSY) have been operational to promote institutional delivery and increase maternal and child survival among the poor. However, the findings reveal that just one-fifth of all births among the abject poor took place at a health centre compared to two-fifths among the poor and three-fifths among the non-poor. Even the natal care services from public health centers are used more by non-poor households compared to poor households, both in rural and urban areas. Owing to cultural practices, some deliveries take place at home but they are assisted by health professionals. Accordingly, we have computed medical assistance at birth by the level of poverty. Only one-fifth of the births to the abject poor mothers received medical assistance 
compared to half among the poor and two-thirds among the non-poor. The rural-urban and state differentials in medical assistance at deliveries are large.

Information on health card and type of vaccination was collected from children born during the five years preceding the survey. Table 7 reports that half of the children belonging to the abject poor households did not have a health card compared to $29 \%$ among the poor but not abject poor and $16 \%$ among the non-poor. It was $8 \%$ among the non-poor in urban areas compared to $36 \%$ among the abject poor in rural areas. The differentials in health card by state shows that more than half of the children among the abject poor in the states of Assam, Bihar, Chhattisgarh, Jharkhand, Madhya Pradesh, Rajasthan and Uttar Pradesh did not even have a health card. Such proportions were much lower among non-poor households.

The state differential in medical assistance at delivery by poverty level showed that it was lowest among the abject poor followed by the poor but not abject poor and the non-poor in all the states except Kerala (Table 8). The state of Kerala is a model state in health care utilization and in the state of human development. In an underdeveloped state like Jharkhand, only $13 \%$ deliveries among the abject poor were assisted by a medical professional compared to $30 \%$ among the poor but not abject poor and 59\% among the non-poor. Similarly, in developed states like Tamil Nadu, 79\% deliveries among mothers of abject poor households received medical attention compared to $88 \%$ among the poor but not abject poor and $95 \%$ among the non-poor. To understand the differentials in medical assistance at delivery among the poor and non-poor in the states, we have computed the ratio in the service coverage of non-poor to abject poor. The closer the ratio is to 1 , the lesser the inequality and vice versa. We found that states such as Kerala, Tamil Nadu, Andhra Pradesh, Goa, Himachal Pradesh and Punjab had a ratio of less than two indicating a smaller inequality in health care among the abject poor and non-poor. On the other 
hand, states such as Meghalaya, Jharkhand, Himachal Pradesh, Uttaranchal, Orissa, Assam, Arunachal Pradesh and Nagaland had a value of three and more indicating higher inequality in the state of health care. All other states had a value between two and three indicating the degree of inequality in maternal health care.

Table 8: Percentage of births received medical assistance by poverty level of households in the states of India, 2005-06

\begin{tabular}{|c|c|c|c|c|c|}
\hline States/India & $\begin{array}{l}\text { Abject } \\
\text { Poor }\end{array}$ & $\begin{array}{l}\text { Poor but not } \\
\text { Abject poor }\end{array}$ & $\begin{array}{l}\text { Non- } \\
\text { poor }\end{array}$ & All & $\begin{array}{l}\text { Ratio of non- } \\
\text { poor to poor }\end{array}$ \\
\hline Meghalaya & 11.7 & 29.2 & 57.1 & 31.3 & 4.9 \\
\hline Jharkhand & 13.3 & 30.2 & 59.0 & 27.8 & 4.4 \\
\hline Uttaranchal & 13.6 & 29.5 & 51.2 & 38.5 & 3.8 \\
\hline Delhi & 21.1 & 53.3 & 76.4 & 64.1 & 3.6 \\
\hline Orissa & 18.7 & 46.7 & 66.7 & 44.0 & 3.6 \\
\hline Assam & 14.0 & 31.6 & 49.5 & 31.0 & 3.5 \\
\hline Arunachal Pradesh & 16.0 & 36.0 & 50.0 & 30.3 & 3.1 \\
\hline Mizoram & 25.0 & 53.8 & 75.0 & 64.7 & 3.0 \\
\hline Tripura & 21.6 & 47.2 & 64.3 & 48.8 & 3.0 \\
\hline Bihar & 17.9 & 32.2 & 52.3 & 29.3 & 2.9 \\
\hline Nagaland & 12.5 & 18.2 & 34.0 & 25.0 & 2.7 \\
\hline West Bengal & 25.3 & 45.7 & 67.5 & 47.6 & 2.7 \\
\hline Madhya Pradesh & 20.8 & 33.2 & 53.6 & 32.7 & 2.6 \\
\hline Haryana & 25.5 & 44.3 & 63.0 & 49.0 & 2.5 \\
\hline Rajasthan & 24.4 & 43.0 & 58.9 & 41.0 & 2.4 \\
\hline Uttar Pradesh & 16.5 & 25.9 & 39.4 & 27.2 & 2.4 \\
\hline Manipur & 28.6 & 54.3 & 67.6 & 58.8 & 2.4 \\
\hline Jammu and Kashmir & 29.3 & 50.0 & 67.5 & 56.6 & 2.3 \\
\hline Chhattisgarh & 24.3 & 44.8 & 52.3 & 41.6 & 2.2 \\
\hline Maharashtra & 37.7 & 64.7 & 80.5 & 68.8 & 2.1 \\
\hline Karnataka & 39.3 & 68.1 & 80.9 & 69.7 & 2.1 \\
\hline Gujarat & 38.3 & 62.1 & 75.8 & 63.0 & 2.0 \\
\hline Punjab & 40.9 & 59.1 & 78.8 & 68.2 & 1.9 \\
\hline Himachal Pradesh & 28.6 & 42.7 & 50.9 & 47.8 & 1.8 \\
\hline Goa & 66.7 & 92.3 & 97.4 & 94.4 & 1.5 \\
\hline Andhra Pradesh & 61.8 & 75.2 & 82.2 & 74.9 & 1.3 \\
\hline Tamil Nadu & 79.1 & 87.8 & 95.0 & 90.6 & 1.2 \\
\hline Kerala & 100.0 & 98.1 & 99.7 & 99.4 & 1.0 \\
\hline India & 23.8 & 45.6 & 66.0 & 46.6 & 2.8 \\
\hline
\end{tabular}


Following medical assistance at birth, we have attempted to understand basic childhood immunization by poverty level in the country. Basic childhood immunization is the most successful and cost effective public health tool in preventing infectious disease during childhood. The World Health Organization under the Expanded Immunization Program in 1974 recommended one dose of BCG, three doses of DPT (diphtheria, pertussis and tetanus), three doses of polio and one dose of the measles vaccine by the first birthday to prevent six major preventable childhood diseases namely, measles, tuberculosis, pertussis (whooping cough), diphtheria, tetanus and poliomyelitis. These vaccines have been integrated into the public health program of many developing countries including India. Usually, the date and type of vaccination of a child are recorded in a health card that is provided either by the health centre or the health worker visiting home.

Table 9: Percentage of children aged 12-59 months by level of poverty and immunization in India, 2000-05

\begin{tabular}{|c|c|c|c|c|c|c|c|c|c|c|c|c|}
\hline \multirow[t]{2}{*}{ India } & \multicolumn{4}{|c|}{ Combined } & \multicolumn{4}{|l|}{ Rural } & \multicolumn{4}{|l|}{ Urban } \\
\hline & $\begin{array}{l}\text { Abject } \\
\text { Poor }\end{array}$ & $\begin{array}{l}\text { Poor } \\
\text { but } \\
\text { not } \\
\text { abject } \\
\text { poor }\end{array}$ & $\begin{array}{l}\text { Non- } \\
\text { poor }\end{array}$ & All & $\begin{array}{l}\text { Abject } \\
\text { Poor }\end{array}$ & $\begin{array}{l}\text { Poor } \\
\text { but } \\
\text { not } \\
\text { abject } \\
\text { poor }\end{array}$ & $\begin{array}{l}\text { Non- } \\
\text { poor }\end{array}$ & All & $\begin{array}{l}\text { Abject } \\
\text { Poor }\end{array}$ & $\begin{array}{l}\text { Poor } \\
\text { but } \\
\text { not } \\
\text { abject } \\
\text { poor }\end{array}$ & $\begin{array}{l}\text { Non- } \\
\text { poor }\end{array}$ & All \\
\hline Combined & & & & & & & & & & & & \\
\hline BCG & 59.5 & 76.9 & 87.8 & 75.7 & 57.7 & 74.3 & 84.6 & 72.4 & 67.2 & 84.9 & 93.9 & 85.4 \\
\hline DPT1 & 55.3 & 74.2 & 85.7 & 72.8 & 53.7 & 71.6 & 82.5 & 69.4 & 62.2 & 82.1 & 92.0 & 82.5 \\
\hline Polio 1 & 86.8 & 92.4 & 95.2 & 91.8 & 86.2 & 91.8 & 94.6 & 90.9 & 89.5 & 94.4 & 96.4 & 94.3 \\
\hline DPT2 & 46.4 & 66.1 & 80.0 & 65.4 & 44.4 & 62.9 & 76.0 & 61.3 & 54.6 & 76.1 & 88.0 & 77.1 \\
\hline Polio 2 & 83.2 & 89.8 & 93.3 & 89.1 & 82.4 & 89.2 & 92.7 & 88.2 & 86.4 & 91.5 & 94.6 & 91.9 \\
\hline DPT 3 & 35.7 & 55.3 & 70.4 & 55.0 & 33.6 & 51.5 & 65.3 & 50.3 & 44.4 & 67.0 & 80.4 & 68.5 \\
\hline Polio 3 & 75.7 & 82.0 & 85.8 & 81.5 & 74.9 & 81.2 & 84.7 & 80.3 & 78.9 & 84.5 & 88.1 & 85.0 \\
\hline Measles & 40.7 & 61.7 & 77.4 & 61.3 & 38.5 & 58.2 & 72.6 & 56.7 & 49.9 & 72.8 & 86.7 & 74.5 \\
\hline $\begin{array}{l}\text { Complete } \\
\text { Immunization }\end{array}$ & 26.0 & 43.5 & 59.0 & 44.0 & 24.2 & 40.0 & 53.6 & 39.4 & 33.8 & 54.7 & 69.7 & 57.2 \\
\hline
\end{tabular}

Childhood vaccinations are estimated for children in the age group 12 to 59 months. We have restricted the analyses to $12-59$ months as the vaccinations are given at different months in the first year of the child's life and measles is the last dose in the vaccination. The differentials in all 
recommended vaccination coverage by poverty level are large, more disadvantageous to the abject poor than to the poor and non-poor. While the difference in polio coverage among the poor and non-poor is small, it is large in DPT and measles. For example, only $36 \%$ of the children belonging to abject poor households had a vaccination of DPT 3 compared to $70 \%$ among the non-poor. Taking all recommended vaccinations into consideration, the complete immunization coverage has been computed which was $26 \%$ among the abject poor, $44 \%$ among the poor and 59\% among the non-poor. The low level of vaccination among the children belonging to abject poor and poor households is a reflection on the services extended to multidimensional poor households. The differentials in measles vaccination to children in the age group 12-59 months also vary largely among the states and are similar to that of medical assistance at birth; it is highest in Kerala and lowest in Nagaland.

\subsection{Poverty and Child Survival}

Evidence across developing countries suggests substantial reduction in infant and child mortality during the last two decades. While immunization of children was primarily attributed in improving child survival in the 1980s, reduction in poverty and malnutrition, improvement in the environmental conditions, the use of health services by the mother were significant factors in the reduction of infant and child mortality in the 1990s (Rutstein 2000; Hatt L.E and Waters H.R 2006). In the Indian context, improvement in the under-five mortality rate is slow and it accounts for about one-fifth of the global under-five mortality rate (You et al 2009). Moreover, the health care services in India, like those in other transitional economies, benefit the non-poor more than the poor.

In this section, we have discussed the differentials in infant mortality rate and the under-five mortality rate by poverty level in India and the states. The IMR and under-five mortality rate are 
also two of the 48 monitoring indicators of the millennium development goals and are directly linked to the state of poverty of the households. We have estimated the IMR and U5MR from the birth history file. The reference period in estimating IMR is five years, while it is ten years for U5MR. We have used the life table method in estimating these mortality indicators. Our findings also reveal that the infant mortality rate and the under-five mortality rate are the highest among the abject poor followed by the poor but not the abject poor and non-poor cutting across the place of residence. The estimated IMR was 64 per 1000 live births among the abject poor, 57 among the poor but not abject poor and 40 among the non-poor in the country (Table 10).

Table 10: Estimated Infant Mortality Rate and the under-five Mortality Rate (U5MR) by Poverty Levels in India, 2000-05

\begin{tabular}{|c|c|c|c|c|c|c|c|c|c|c|c|c|}
\hline \multirow[t]{2}{*}{ Poverty } & \multicolumn{4}{|c|}{ Combined } & \multicolumn{4}{|l|}{ Rural } & \multicolumn{4}{|c|}{ Urban } \\
\hline & IMR & $\begin{array}{l}\text { Relative } \\
\text { standard } \\
\text { error }(\%)\end{array}$ & $\begin{array}{l}\text { U5 } \\
\text { MR }\end{array}$ & $\begin{array}{l}\text { Relative } \\
\text { standard } \\
\text { error }(\%)\end{array}$ & IMR & $\begin{array}{c}\text { Relative } \\
\text { standard } \\
\text { error } \\
(\%)\end{array}$ & $\begin{array}{c}\mathrm{U} 5 \mathrm{M} \\
\mathrm{R}\end{array}$ & $\begin{array}{l}\text { Relative } \\
\text { standard } \\
\text { error }(\%)\end{array}$ & $\begin{array}{c}\mathrm{IM} \\
\mathrm{R}\end{array}$ & $\begin{array}{c}\text { Relative } \\
\text { standard } \\
\text { error } \\
(\%)\end{array}$ & $\begin{array}{l}\text { U5 } \\
\text { MR }\end{array}$ & $\begin{array}{c}\text { Relative } \\
\text { standard } \\
\text { error }(\%)\end{array}$ \\
\hline \multicolumn{13}{|l|}{ Overall poverty } \\
\hline Non- poor & 40 & 3.5 & 53 & 2.1 & 48 & 4.2 & 64 & 2.5 & 31 & 5.8 & 38 & 3.7 \\
\hline Moderate Poor & 57 & 3.2 & 78 & 1.9 & 60 & 3.8 & 85 & 2.2 & 53 & 5.5 & 65 & 3.4 \\
\hline Abject poor & 64 & 3.6 & 102 & 2.0 & 67 & 4.2 & 110 & 2.2 & 57 & 7.0 & 84 & 3.9 \\
\hline $\begin{array}{l}\text { Poor including } \\
\text { abject poor }\end{array}$ & 60 & 2.3 & 88 & 1.4 & 63 & 2.9 & 99 & 1.5 & 54 & 4.3 & 74 & 2.6 \\
\hline $\begin{array}{l}\text { All } \\
\text { Health } \\
\text { Dimension }\end{array}$ & 52 & 1.9 & 73 & 1.1 & 57 & 2.3 & 84 & 1.3 & 42 & 3.6 & 56 & 2.1 \\
\hline Health poor & 56 & 2.1 & 88 & 1.9 & 60 & 3.7 & 95 & 2.2 & 49 & 6.3 & 70 & 3.9 \\
\hline \multicolumn{13}{|l|}{$\begin{array}{l}\text { Education } \\
\text { Dimension }\end{array}$} \\
\hline $\begin{array}{l}\text { Educationally } \\
\text { poor }\end{array}$ & 64 & 3.4 & 95 & 1.8 & 65 & 3.8 & 100 & 2.0 & 60 & 7.2 & 80 & 3.9 \\
\hline $\begin{array}{l}\text { Educationally } \\
\text { Non-poor } \\
\text { Wealth } \\
\text { Dimension }\end{array}$ & 47 & 2.3 & 63 & 1.4 & 54 & 3.0 & 74 & 1.8 & 39 & 3.8 & 49 & 2.4 \\
\hline Wealth poor & 64 & 3.3 & 99 & 1.8 & 69 & 5.5 & 112 & 2.1 & 57 & 5.6 & 83 & 3.1 \\
\hline $\begin{array}{l}\text { Wealth Non- } \\
\text { poor }\end{array}$ & 47 & 2.3 & 63 & 1.4 & 53 & 2.8 & 73 & 1.6 & 36 & 4.4 & 45 & 2.9 \\
\hline
\end{tabular}

The estimated under-five mortality rate was 102 among the abject poor, 78 among the poor but not abject poor and 53 among the non-poor. The IMR and under-five mortality were higher in rural areas compared to urban areas. 
Table 11: Estimated Infant Mortality Rate (IMR) and under five Mortality Rate among abject poor, poor but not abject poor and non-poor in states of India, 2000-05 (ascending order of IMR among abject poor)

\begin{tabular}{|c|c|c|c|c|c|c|c|c|c|}
\hline \multirow[b]{2}{*}{ Sr No } & \multirow[b]{2}{*}{ States } & \multicolumn{3}{|c|}{ Infant Mortality Rate (IMR) } & \multirow[b]{2}{*}{ All } & \multicolumn{4}{|c|}{ Under five Mortality Rate (U5MR) } \\
\hline & & $\begin{array}{l}\text { Abject } \\
\text { poor }\end{array}$ & $\begin{array}{l}\text { Poor but } \\
\text { not abject } \\
\text { poor }\end{array}$ & $\begin{array}{l}\text { Non- } \\
\text { poor }\end{array}$ & & $\begin{array}{l}\text { Abject } \\
\text { poor }\end{array}$ & Poor & $\begin{array}{l}\text { Non- } \\
\text { poor }\end{array}$ & All \\
\hline 1 & Jharkhand & 83 & 68 & 38 & 67 & 101 & 95 & 68 & 101 \\
\hline 2 & Uttar Pradesh & 82 & 73 & 66 & 73 & 130 & 102 & 85 & 105 \\
\hline 3 & Tripura & 79 & 49 & 38 & 51 & $* *$ & 58 & 42 & 68 \\
\hline 4 & Madhya Pradesh & 78 & 64 & 49 & 64 & 93 & 93 & 63 & 76 \\
\hline 5 & Arunachal Pradesh & 74 & 65 & 49 & 64 & 100 & 101 & 69 & 94 \\
\hline 6 & Rajasthan & 73 & 70 & 56 & 67 & 100 & 103 & 72 & 93 \\
\hline 7 & Mizoram & 69 & 50 & 23 & 43 & 53 & 67 & 40 & $* *$ \\
\hline 8 & Assam & 68 & 76 & 51 & 66 & 89 & 84 & 64 & 89 \\
\hline 9 & Manipur & 65 & 39 & 21 & 32 & 75 & 54 & 38 & 48 \\
\hline \multirow[t]{2}{*}{10} & Delhi & 65 & 54 & 33 & 44 & 69 & 75 & 36 & 52 \\
\hline & India & 64 & 57 & 40 & 52 & 102 & 78 & 53 & 73 \\
\hline 11 & Punjab & 62 & 59 & 41 & 44 & 63 & 75 & 41 & 54 \\
\hline 12 & Chhattisgarh & 61 & 79 & 77 & 73 & 99 & 94 & 80 & 99 \\
\hline 13 & Uttaranchal & 61 & 54 & 29 & 42 & 88 & 90 & 52 & 70 \\
\hline 14 & Jammu and Kashmir & 60 & 45 & 42 & 45 & 71 & 56 & 46 & 52 \\
\hline 15 & Gujarat & 59 & 63 & 36 & 51 & 76 & 76 & 64 & 76 \\
\hline 16 & Bihar & 57 & 67 & 67 & 63 & 100 & 83 & 76 & 91 \\
\hline 17 & Sikkim & 54 & 34 & 33 & 35 & 35 & 46 & 43 & 43 \\
\hline 18 & Nagaland & 52 & 48 & 33 & 64 & 93 & 69 & 55 & 66 \\
\hline 19 & Orissa & 52 & 62 & 74 & 62 & 89 & 79 & 73 & 89 \\
\hline 20 & West Bengal & 51 & 59 & 37 & 48 & 61 & 67 & 43 & 61 \\
\hline 21 & Karnataka & 45 & 52 & 38 & 45 & 67 & 77 & 51 & 67 \\
\hline 22 & Maharashtra & 45 & 47 & 33 & 39 & 52 & 59 & 42 & 52 \\
\hline 23 & Meghalaya & 44 & 52 & 39 & 46 & $* *$ & 69 & 47 & 63 \\
\hline 24 & Haryana & 43 & 40 & 47 & 43 & 53 & 62 & 50 & 55 \\
\hline 25 & Andhra Pradesh & 42 & 43 & 40 & 41 & 61 & 68 & 46 & 61 \\
\hline 26 & Tamil Nadu & 29 & 42 & 25 & 31 & 46 & 56 & 39 & 46 \\
\hline 27 & Himachal Pradesh & $* *$ & 35 & 31 & 32 & 42 & 53 & 36 & 41 \\
\hline 28 & Goa & $* *$ & 18 & 15 & 15 & 30 & 47 & 22 & 30 \\
\hline 29 & Kerala & $* *$ & 18 & 14 & 15 & 20 & 18 & 20 & 20 \\
\hline
\end{tabular}

** Not estimated due to small size of sample

Table 11 reports the estimated IMR and the under-five mortality rate for the states of India. In general, the estimated IMR and under-five mortality rate follows a pattern similar to that of the national average; it is maximum among the abject poor followed by the poor but not abject poor, 
and minimum among the non-poor. For example, the estimated IMR among the abject poor in Jharkhand was 83 per 1000 live births compared to 68 among the poor but not abject poor and 38 among the non-poor. Similarly in Uttar Pradesh, the estimated IMR was 82 per 1000 live births among the abject poor compared to 73 among the poor and 66 among the non-poor.

For comparative purposes, we have classified the states on the basis of differences of IMR among the abject poor and the non-poor. We found that there are eight states, namely, Arunachal Pradesh, Jharkhand, Tripura, Mizoram, Manipur, Uttaranchal, Madhya Pradesh and New Delhi, where the differences are more than 25 points. There are ten mores states (Uttar Pradesh, Rajasthan, Assam, Nagaland, Gujarat, West Bengal, Jammu and Kashmir, Punjab and Sikkim) where the differences are between 10 to 25 points and in the remaining states, the differences are small. This brought out the interstate differentials in IMR and U5MR within the country. However, there are four states (out of 29 states) where the estimated IMR among the abject poor or poor but not abject poor is lower than that of the non-poor. These states are Haryana, Bihar, Chhattisgarh and Orissa. This is probably due to misreporting of infant deaths as the level of female literacy is low in these states. These states also have higher estimates of IMR among the poor but not abject poor, than among the abject poor. There are two more states, namely, Assam and Meghalaya where the estimated IMR among the abject poor is lower by 5 points or more, to those of poor but not abject poor, probably due to lower sample size. The pattern is similar for the under-five mortality rate. We have not provided the estimated IMR of the abject poor in the states of Himachal Pradesh, Goa and Kerala because the size of the sample is small. The standard error of IMR and U5MR by poverty class is also shown in Appendix 1. 
Table 12: Estimated Infant Mortality Rate and under-five Mortality Rate among dimensional poor in states of India, 2000-05 (arranged in ascending order of U5MR among wealth poor)

\begin{tabular}{|c|c|c|c|c|c|c|c|}
\hline \multirow[b]{2}{*}{ Sr No } & \multirow[b]{2}{*}{ States/ India } & \multicolumn{3}{|c|}{ Infant Mortality Rate (IMR) } & \multicolumn{3}{|c|}{ Under five Mortality Rate (U5MR) } \\
\hline & & $\begin{array}{l}\text { Wealth } \\
\text { Poor }\end{array}$ & $\begin{array}{c}\text { Educationally } \\
\text { Poor }\end{array}$ & $\begin{array}{l}\text { Health } \\
\text { Poor }\end{array}$ & $\begin{array}{l}\text { Wealth } \\
\text { Poor }\end{array}$ & $\begin{array}{c}\text { Educationally } \\
\text { Poor }\end{array}$ & $\begin{array}{l}\text { Health } \\
\text { Poor }\end{array}$ \\
\hline 1 & Uttar Pradesh & 80 & 75 & 78 & 128 & 118 & 118 \\
\hline 2 & Arunachal Pradesh & 75 & 73 & 70 & 118 & 89 & 10 \\
\hline 3 & Madhya Pradesh & 85 & 76 & 63 & 117 & 118 & 117 \\
\hline 4 & Jharkhand & 80 & 74 & 74 & 115 & 114 & 115 \\
\hline 5 & Assam & 71 & 83 & 75 & 110 & 112 & 110 \\
\hline 6 & Rajasthan & 76 & 67 & 66 & 107 & 100 & 95 \\
\hline 7 & Bihar & 65 & 66 & 47 & 105 & 95 & 92 \\
\hline 8 & Chhattisgarh & 60 & 70 & 74 & 105 & 129 & 105 \\
\hline 9 & Orissa & 58 & 58 & 50 & 105 & 114 & 105 \\
\hline 10 & Meghalaya & 44 & 52 & 38 & 104 & 76 & 104 \\
\hline 11 & Gujarat & 63 & 63 & 56 & 102 & 89 & 84 \\
\hline 12 & Punjab & 85 & 52 & 56 & 102 & 56 & 69 \\
\hline 13 & Uttaranchal & 83 & 76 & 45 & 101 & 11 & 69 \\
\hline 14 & Nagaland & 63 & 49 & 16 & 93 & 79 & 45 \\
\hline 15 & Tripura & 52 & 102 & 73 & 88 & 117 & 88 \\
\hline 16 & $\begin{array}{l}\text { Jammu and } \\
\text { Kashmir }\end{array}$ & 80 & 75 & 78 & 85 & 65 & 52 \\
\hline 17 & Karnataka & 44 & 49 & 47 & 81 & 88 & 73 \\
\hline 18 & Maharashtra & 55 & 44 & 39 & 78 & 69 & 63 \\
\hline 19 & Mizoram & 58 & 38 & 62 & 76 & 34 & 76 \\
\hline 20 & New Delhi & 63 & 46 & 63 & 75 & 63 & 78 \\
\hline 21 & Himachal Pradesh & $* * *$ & 61 & 27 & 74 & 80 & 35 \\
\hline 22 & West Bengal & 48 & 50 & 69 & 72 & 77 & 72 \\
\hline 23 & Manipur & 56 & 56 & 34 & 71 & 48 & 79 \\
\hline 24 & Andhra Pradesh & 35 & 50 & 41 & 71 & 90 & 71 \\
\hline & India & 64 & 63 & 56 & 64 & 64 & 56 \\
\hline 25 & Sikkim & 67 & 39 & 39 & 60 & 36 & 47 \\
\hline 26 & Haryana & 34 & 58 & 36 & 55 & 66 & 58 \\
\hline 27 & Tamil Nadu & 38 & 42 & 39 & 51 & 63 & 47 \\
\hline 28 & Goa & 9 & $* *$ & 17 & 48 & 69 & 40 \\
\hline 29 & Kerala & $* * *$ & $* * *$ & 12 & 34 & 57 & 11 \\
\hline
\end{tabular}


We examined the differentials in IMR and under-five mortality rate with respect to education, health and wealth poor and non-poor (Table 10 and Table 12). We found that there are no significant differences in both IMR and U5MR with respect to the wealth poor and the education poor at the national level. However, the estimates are marginally lower among the health poor compared to the wealth poor or education poor. For example, the estimated IMR among the education and wealth poor households was 64 each per 1000 live births and 56 among the health poor. However, at the state level there is a mixed pattern. There are twelve states where the estimates of IMR among the educational poor are the same or more than those among the wealth poor. These states are Tripura, Assam, Chhattisgarh, Bihar, Gujarat, Orissa, Haryana, Manipur, Meghalaya, West Bengal, Karnataka and Tamil Nadu. Similarly, there are eight states namely, Tripura, Assam, West Bengal, Andhra Pradesh, Karnataka, New Delhi, Tamil Nadu and Mizoram where the estimated IMR among the health poor is more than that of the wealth poor. In all other states, the IMR among the wealth poor is higher than that of the educationally poor and health poor. Even in these states, the level of IMR is quite high among the educationally poor or health poor. The pattern is similar with respect to U5MR.

\section{Discussion}

With the evolution of the human development paradigm (UNDP 1990) and the capability deprivation (Sen 1985, 1999), a shift from money metric poverty to multidimensional poverty has been envisaged in national and international development agenda. However, the measurement and application of multidimensional poverty is limited in many developing countries including India. Though there are concerted efforts to alleviate multidimensional poverty through various developmental schemes like the National Rural Health Mission 
(NRHM), the National Rural Employment Guarantee Scheme (NREGS), Sarva Siksha Abhiyan (SSA), the official estimates of poverty in India are still confined to money-metric poverty, derived from consumption expenditure data.

In this paper, we have attempted to estimate multidimensional poverty in India using the most recent round of National Family and Health Survey data and examined the state of child health among the abject poor, poor but not abject poor and non-poor households. The choices of indicators are context specific and subject to the availability of data. However, many of the indicators we have used are commonly used and available in a large number of developing countries. Four of the health care and child health indicators used in the analyses (medical assistance at delivery, coverage of measles vaccination, the infant mortality rate and the underfive mortality rate) are the monitoring indicators of MDGs. We have used the most simplified and practical method of deriving dimensional poor; multidimensional poverty is derived using the union approach. Our results show that about half of India's population is poor and one-fifth are abject poor (poor in two or all three dimensions) with large rural-urban and inter-state differentials. These estimates are substantially higher compared to the official estimates of poverty for all the states of India. We found that abject poor households had limited access to financial institutions, health insurance schemes and that a higher proportion of abject poor are excluded from the poverty eradication program. The findings of higher poverty among female headed households, large households and households with little or no education (of head of household) are consistent with the findings from other studies. The correlations of wealth and education poor are higher than that of wealth and health. The extent of abject poverty and overall poverty is maximum in the state of Bihar and minimum in the state of Kerala. It follows the general state of human development observed among the states of India (Planning Commission 
2004). With respect to health care utilization, the poorest of the poor (abject poor) are the disadvantaged in all states with the exception of Kerala. When we compared the three fold differentials (among abject poor and non-poor) in health care utilization with that of wealth quintiles as defined in NFHS 3 (fifth and first quintiles), we found that our differences are large which validates the utility of deriving multidimensional poverty. The estimated infant mortality rate and the under-five mortality rate are substantially higher among the abject poor compared to the poor and non-poor across all states. Further, we observed that there are no significant differentials in estimates of IMR and under-five mortality rate among the education poor and wealth poor households and the differences with health poor households are marginally lower than that of the wealth poor at the national level. At the state level, there are varying patterns with twelve states having equal or higher estimated IMR among the education poor compared to the wealth poor. Similarly, there are eight states where the estimated IMR among the health poor is higher than that of the wealth poor. This indicates that all these dimensions are equally important in devising strategies to promote child survival and calls for integrating multidimensional poverty in planning and program implementation. Further, the large differentials in health care utilization, the infant mortality rate and the under-five mortality rate among the abject poor and poor not only validates our measure of multidimensionality poverty but also depicts the poor state of child health in the country. This differential holds good by place of residence and among the states. We acknowledge that this study could not provide the estimates of infant and child mortality for the smaller states in India because the size of the sample was small and limited to the indicators available in the data set.

From policy perspectives, multidimensional poverty clearly demonstrates the multiple deprivation of a household in the key domain of human development, that is, education, health 
and living standard and its linkage with inequality in health care utilization and health of the population. The multidimensional poverty index will serve better for policy formulation as it can address the growing inequality in health care utilization and health outcome among population sub-groups in the country effectively. The large differentials in health care utilization and child survival among abject poor and non-poor (for example three-fifth of births among abject poor received a medical assistance compared to one-fifth among the abject poor) clearly demonstrate the utility of focusing multiple deprivations in policy and program to reduce inequality in healthcare utilization. Also, the small differences in IMR and U5MR among the education poor, wealth poor and health poor demonstrated that the MDGs are interconnected and therefore the need to address these together.

\section{Research and Policy Implications}

The implications of the findings of this study are both for research and policy. With respect to research, the paper demonstrated the robust measurement of multidimensional poverty and its linkages with child survival and health care utilization using data from a large scale population based survey. The selection of indicators is illustrative and contextual. We recommend that data collected in a number of population based surveys such as the Demographic and Health Surveys (DHS), World Health Survey (WHS), the Multiple Indicator Cluster Surveys (MICS) etc can be used to develop the measurement of multidimensional poverty at national and sub-national levels. It is also useful to link multidimensional poverty with process and outcome indicators such as health care utilization, health and health inequality in the population and derive inferences for evidence based planning. 
Based on the findings, the foremost policy implication from the study is to take note of the exclusion of a high proportion of the abject poor in BPL programs which are specifically designed for conditional cash transfer and eradicating extreme poverty. That only two-fifths of abject poor households had a BPL card is an indication that majority of the poor are excluded from the poverty eradication program. Hence, the inclusion criterion and the transparency in the allocation of BPL cards need to be examined so as to reduce poverty. Second, we recommend moving from the long contested measure of consumption poverty to multidimensional poverty in planning and program implementation of the centre and state governments, by developmental agencies and various organizations. The Planning Commission has already recognized the multidimensional nature of poverty. We suggest more research to be undertaken so as to arrive at more precise estimates of poverty. We also suggest in using multidimensional poverty as one of the criteria in the transfer of fiscal resources from the centre to the state. Among other factors, the $13^{\text {th }}$ Finance Commission recommended deprivation and percentage of Scheduled Castes and Tribes in rural areas (based on 2001 census) as criteria in the transfer of central funds to the states (Ministry of Finance 2009). We suggest using scientific measures as illustrated in the analyses and increase the weightage of deprivation in transfer of resources. Given the federal structure and diversity in socio economic development in India, there is a need for general consensus among the states of India to fight poverty together. Such a collective effort and consensus among the states of India will be similar to the commitment of developing and developed countries in achieving the MDGs. Finally we recommend protective measures in health care utilization for the abject poor irrespective of caste, creed, religion and space so as to address the equity issues to realize the MDGs. 


\section{References}

Alkire Sabina. (2007). The missing dimensions of poverty data: Introduction to the special issue, Oxford Development Studies, 35 (4), 347-359.

Alkire Sabina and James Foster,(2009). Counting and multidimensional poverty measures, OPHI Working Paper No 7.5.

Booysen F; Michael Von Maltitz \& Gideon Du Rand.(2008). Using an asset index to assess trends in poverty in seven Sub-Saharan African countries. World Development, 36(6), 1113-1130.

Bourguignon, F and Chakravarty, S.R. (2003). The measurement of multidimensional poverty, Journal of Economic Inequality, 1(1), 25-49.

Calvo Cesar. (2008). Vulnerability to Multidimensional Poverty: Peru, 1998-2002, World Development, 36(6), 1011-1020.

Deutsch, J; and Silber, J.(2005). Measuring multidimensional poverty: An empirical comparison of various approaches. Review of Income and Wealth, 5(1), 145-174.

Filmer, D. and Pritchett, L.H. (2001). Estimating wealth effects without expenditure data- or tears: An application to educational enrolments in states of India, Demography, 38 (1), 115-132.

Gwatkin, D.R. (2005). How much would poor people from faster progress towards the millennium development goals for health? Lancet, 365,813-817

Gordon, D; Namdy, S., Pantazis, C., Pemberton, S. and Towsend, P. (2003). The distribution of child poverty in the developing world, Bristol: Centre for International Poverty Research

Hatt L.E, Waters H.R.( 2006). Determinants of child mortality in Latin America: a pooled analysis of interactions between parental education and economic status. Social Science Medicine, 62 (2), 375-386.

International Institute for Population Sciences (IIPS) and Macro International.,(2007). National Family Health Survey (NFHS 3), 2005-06; India: Volume I. Mumbai: IIPS.

International Institute for Population Sciences (IIPS) and Macro International.,(2007). National Family Health Survey (NFHS 3), 2005-06; India: Volume II. Mumbai: IIPS.

Klasen, S. (2000). Measuring poverty and deprivation in South Africa, Review of Income and Wealth, 46 (1), 33-58.

Ministry of Health and Family Welfare(MOHFW). (2005). National Rural Health Mission (2005-12). Department of Family Welfare, Govt. of India, New Delhi, India. 
Finance. (2009). Report of the Thirteenth Finance Commission 2010-15, Vol (1), Department of Economic Affairs, Govt. of India, new Delhi, India

Mohanty, S.K. (2009). Alternate Wealth Index and Health Estimates in India, Genus, $65(2), 113-137$

Mohanty S.K and Praveen K. Pathak . (2009). Rich-poor gap in utilization of reproductive and child health care services in India, 1992-2005", Journal of Biosocial Sciences, 41(3),381398.

Planning Commission, Government of India. (2007). Poverty estimates for 2004-05, accessed on line: http://planningcommission.nic.in/news/prmar07.pdf.

Planning Commission, Government of India. (2009). Report of the expert group to review the methodology for estimation of poverty

Ram F, S.K. Mohanty \& Usha Ram. (2009). Understanding the distribution of BPL cards: AllIndia and selected states, Economic Political Weekly, 44 (7), 66-71.

Rutstein S. (2000). "Factors associated with trends in infant and child mortality in developing countries during the 199s". Bulletin of the World Health Organsiation 2000; 78(10): 12561270

Rutstein, S., Johnson, K.(2004).The DHS Wealth Index in DHS Comparative Reports. ORC Macro.

Sahn,D.E; \& Stifel, D.C.(2000).Poverty comparison over-time and across countries in Africa. World Development, 28(12), 2123-2155.

Sen, A.K.(1992). Inequality reexamined. Cambridge: Harvard University Press.

Sen, A.K.(1999). Development as freedom. New York: Knoff Press

Srinivasan K and Mohanty S.K.(2008). "Household deprivation and its linkages with reproductive and child health care and health outcome, Economic Political Weekly, 43 (48), 67-76

Sundaram, K. (2003). On identification of households below poverty line: some comments on the proposed methodology, Economic and Political Weekly, 38 (9), 896-902.

UNDP . (1990). Human Development Report, Oxford University Press, New York

UNDP. (1997). Human Development Report, Oxford University Press, New York

UNDP (2010) . Human Development Report, Palgrave Macmillan, New York

Wagle .U. (2008). "Multidimensional poverty: An alternative measurement approach for the United states?", Social Science Research, 37, 559-580. 
Wang Limin . (2003). "Determinants of child mortality in LDCs: Empirical findings from demographic and health surveys", Health Policy, 65 (3), 277-299.

You danzhen, Tessa Wardlaw, Peter Salama, Gareth Jones .(2009). Levels and trends in under-5 mortality, 1990-2008, Lancet S 0140-6736(09), 61601-9 
Appendix 1: Standard error of estimated IMR and U5MR by poverty class in states of India (per 1000)

\begin{tabular}{|c|c|c|c|c|c|c|c|c|c|c|c|c|c|c|c|}
\hline \multirow{3}{*}{$\begin{array}{c}\mathrm{Sr} \\
\mathrm{No}\end{array}$} & \multirow[b]{3}{*}{ States } & \multirow{2}{*}{\multicolumn{8}{|c|}{ Standard Error }} & \multicolumn{6}{|c|}{ Standard Error } \\
\hline & & & & & & & & & & & & & MR & & \\
\hline & & $\begin{array}{l}\text { Abject } \\
\text { poor }\end{array}$ & $\begin{array}{l}\text { Poor but } \\
\text { not abject } \\
\text { poor }\end{array}$ & $\begin{array}{l}\text { Non- } \\
\text { poor }\end{array}$ & $\begin{array}{l}\text { Wealth } \\
\text { Poor }\end{array}$ & $\begin{array}{l}\text { Education } \\
\text { al poor }\end{array}$ & $\begin{array}{l}\text { Health } \\
\text { poor }\end{array}$ & All & $\begin{array}{l}\text { Abject } \\
\text { poor }\end{array}$ & $\begin{array}{l}\text { Poor but } \\
\text { not abject } \\
\text { poor }\end{array}$ & $\begin{array}{l}\text { Non- } \\
\text { poor }\end{array}$ & All & $\begin{array}{l}\text { Wealth } \\
\text { Poor }\end{array}$ & $\begin{array}{l}\text { Educati } \\
\text { onal } \\
\text { Poor }\end{array}$ & $\begin{array}{l}\text { Health } \\
\text { Poor }\end{array}$ \\
\hline 1 & Andhra Pradesh & 10 & 7 & 6 & 8 & 10 & 8 & 4 & 4 & 6 & 5 & 4 & 7 & 8 & 7 \\
\hline 2 & Arunachal Pradesh & 15 & 14 & 16 & 13 & 14 & 16 & 9 & 13 & 12 & 12 & 7 & 12 & 10 & 14 \\
\hline 3 & Assam & 12 & 11 & 11 & 10 & 15 & 11 & 7 & 5 & 8 & 8 & 5 & 8 & 11 & 8 \\
\hline 4 & Bihar & 7 & 10 & 12 & 8 & 7 & 7 & 5 & 7 & 8 & 9 & 4 & 7 & 6 & 7 \\
\hline 6 & Goa & $* *$ & 9 & 5 & 8 & $* *$ & 10 & 4 & 4 & 10 & 4 & 4 & 14 & 19 & 12 \\
\hline 7 & Gujarat & 13 & 10 & 8 & 13 & 14 & 9 & 6 & 5 & 8 & 7 & 5 & 12 & 11 & 8 \\
\hline 8 & Haryana & 14 & 9 & 9 & 15 & 14 & 8 & 6 & 11 & 8 & 7 & 5 & 14 & 10 & 8 \\
\hline 9 & Himachal Pradesh & $* *$ & 11 & 7 & $* *$ & 30 & 10 & 6 & 24 & 10 & 5 & 4 & 32 & 21 & 9 \\
\hline 10 & Jammu and Kashmir & 19 & 10 & 8 & 24 & 14 & 10 & 6 & 16 & 7 & 6 & 5 & 23 & 9 & 9 \\
\hline 11 & Jharkhand & 10 & 11 & 10 & 10 & 10 & 10 & 6 & 5 & 10 & 9 & 5 & 8 & 8 & 8 \\
\hline 12 & Karnataka & 11 & 8 & 6 & 11 & 10 & 8 & 5 & 4 & 7 & 5 & 4 & 10 & 8 & 8 \\
\hline 13 & Kerala & $* *$ & 8 & 4 & 35 & $* *$ & 8 & 4 & 3 & 7 & 4 & 3 & 17 & 39 & 6 \\
\hline 15 & Maharashtra & 11 & 7 & 5 & 9 & 11 & 7 & 4 & 3 & 5 & 4 & 3 & 7 & 8 & 7 \\
\hline 16 & Manipur & 16 & 8 & 4 & 11 & 13 & 11 & 4 & 12 & 7 & 4 & 4 & 9 & 8 & 13 \\
\hline 17 & Meghalaya & 12 & 11 & 11 & 11 & 11 & 10 & 7 & & 9 & 9 & 7 & 13 & 9 & 13 \\
\hline 18 & Mizoram & 30 & 15 & 7 & 20 & 22 & 19 & 6 & 18 & 13 & 6 & $* *$ & 17 & 13 & 17 \\
\hline 19 & Nagaland & 12 & 8 & 6 & 10 & 9 & 9 & 4 & 12 & 7 & 5 & 4 & 9 & 7 & 13 \\
\hline 20 & New Delhi & 18 & 12 & 7 & 14 & 14 & 16 & 6 & 13 & 10 & 5 & 5 & 11 & 11 & 14 \\
\hline 21 & Orissa & 9 & 10 & 11 & 8 & 11 & 9 & 6 & 5 & 8 & 8 & 5 & 8 & 10 & 8 \\
\hline 22 & Punjab & 20 & 12 & 7 & 29 & 14 & 12 & 6 & 15 & 9 & 5 & 5 & 21 & 9 & 10 \\
\hline 23 & Rajasthan & 10 & 9 & 10 & 11 & 9 & 9 & 6 & 8 & 8 & 8 & 5 & 8 & 7 & 7 \\
\hline 24 & Sikkim & 30 & 12 & 10 & 37 & 17 & 15 & 7 & 15 & 9 & 8 & 6 & 24 & 9 & 11 \\
\hline 25 & Tamil Nadu & 13 & 8 & 5 & 10 & 16 & 10 & 4 & 4 & 7 & 4 & 4 & 8 & 11 & 8 \\
\hline 26 & Tripura & 23 & 15 & 12 & 15 & 31 & 18 & 9 & & 12 & 8 & 6 & 14 & 21 & 14 \\
\hline 27 & Uttar Pradesh & 6 & 5 & 5 & 6 & 5 & 5 & 3 & 5 & 4 & 4 & 3 & 5 & 4 & 5 \\
\hline 28 & Uttaranchal & 19 & 11 & 7 & 24 & 20 & 10 & 6 & 15 & 10 & 6 & 5 & 17 & 15 & 9 \\
\hline 29 & West Bengal & 9 & 9 & 6 & 8 & 9 & 10 & 5 & 4 & 7 & 5 & 4 & 7 & 7 & 7 \\
\hline
\end{tabular}

** Not estimated 